\title{
Dependency Theory and Global Economic Imbalance: A Critique
}

\author{
Chuka Enuka \\ http://dx.doi./org/10.4314/ujah.v19i1.7
}

\section{Abstract}

The present world economic order is based on domination and inequality. The world is bifurcated into two asymmetrical groups of countries: the North and the South. While the economies of the North are generally strong, industrialized, and self-reliant, those of the South are predominantly weak, disarticulated, unindustrialized, appendage and dependent on the North. Explanations for this reality of inequality and disparity in the levels of development in the world have precipitated scholarly debates, postulations and theoretical formulations. Among such theories is the dependency theory. As a theory of development and underdevelopment studies and an analytical framework within the discipline of international economic relations, the dependency theory discusses the reality of underdevelopment and global economic imbalance in the international system. It rejects underdevelopment as a natural condition of the poor societies of the South, and links underdevelopment to dependence, a situation which history of colonial imperialism has left and which modern imperialism creates in underdeveloped countries. This paper argues that though the dependency theory possesses appreciable explanatory capability for the unfortunate global economic disparity, but it is not without limitations. The paper challenges the methodological and conceptual correctness of the propositions underlying a number of dependency theoretical assumptions. It recommends that looks should be taken beyond the theoretical 
offers of dependency for a wholesome understanding of failure of development in the third world, and explanation for the present global economic imbalance.

\section{Introduction}

It is a reality that the world we live in, is a bi-divided one, developmentally. Variance is quick to be noticed when developmental levels of countries that make up the globe is considered. As succinctly put by Indira "The present world economic order is based on domination and inequality" (Onimode 2012). Why should we have growing wealth with rising poverty in the world?. Why should some $20 \%$ of the population of the world persistently consume about $80 \%$ of the world resources? Explanation for this reality of imbalance in the world economy has attracted the formulation and employment of theories as frameworks for comprehension and analysis of this unbalanced character of the global economy.

Among these explanatory frameworks is the Modernization school, which blames failure of development on endogenous reasons rather than exogenous explanations. The central thesis of the modernization school is that underdevelopment in the Third World is internally generated and perpetuated due to the traditional/primitive character of these societies, and lack of selfachievement oriented policies. Proponents of this school like Rostow, blames underdevelopment on the Third World's failure to westernize, or to follow the same developmental path taken earlier by the developed countries in the West: a progressive journey from a traditional, pre-industrial, agrarian society towards a modern, industrial, mass-consumption society (Jackson and Sorenson 2007). The dependency theory, which this paper critiques, is a rejection of the traditional modernization theories as complete 
explanation for Africa's and indeed Third World's underdevelopment. As a theory, it links underdevelopment to economic dependence, and this according the proponents of the dependency school, has a historical process. Far from being an original or natural condition of the poor societies, underdevelopment is a condition imposed by the international expansion of capitalism and its inalienable partner, imperialism. This paper explores and tests the capability of the dependency theory as an explanatory framework for the world's unequal economic relations. In doing this, reference is limited to African case as a sample for the larger parts of the world designated third.

\section{Clarifying Dependency Theory}

Majorly from the economic perspective, Claude Ake views dependence as a case where "An economy is dependent to the extent that its position and relations to other economies in the international system and the articulation of its internal structure make it incapable of autocentric development" (Ake 1981: 55). As defined by Theotonia Santos, dependency is "A situation in which a certain group of countries have their economy conditioned by the development and expansion of another economy" (Santos 1970). S

Santos went further to argue that the basic situation of dependence leads to global situation in dependent countries that situate them in backwardness and under the exploitation of the dominant countries (Santos 1970). To Dingson (2001), this is the economic and political reliance of a state on another. Dale Johnson's conceptualization of dependency sees it as "...imperialism seen from the perspective of underdevelopment." Offiong (1981) argued that in the dependency situation, crucial economic decisions are made, not by the countries that are being 
developed, but by foreigners whose interest are carefully safeguarded. Offiong opines further that dependency is a conditioning situation in which the specific histories of development and underdevelopment transpire in various societies. In line with this thought, dependency is what the history of colonial imperialism creates in underdeveloped countries. Suffice it to say that dependency is a situation of unprogressive reliance on one by another for survival. In the African case, this is colonially and neo-colonially conditioned.

Though dependency theory arose in Latin America in the 1960s as an alternative to the modernization theory, the theoretical and philosophical foundations of the underdevelopment paradigm could be traced to the works of such radical scholars like Karl Marx whose seminal works and elaborate analysis of such logical issues as labour theory of surplus value, colonialism and imperialism exerted and have continued to exert profound impact on the postulations of contemporary writers on dependency. As a response and panacea to the problems and challenges of development in Latin America, the United Nations Economic Commission for Latin America, advocated autonomous national development and import-substitution strategy as viable policy options to stimulate development in Latin American countries.

The failure of import-substitution strategy as advocated by the United Nations Economic Commission for Latin America to foster economic development on one hand, and the failure of western-oriented paradigms to offer appropriate and adequate mechanism for national development on the other, stimulated the emergence of dependency theory. As captured by Okereke and Ekpe (2002: 58) "Dependency theory arose in Latin America in the $1960 \mathrm{~s}$ in response to the alleged failure both of continental development and of theories attempting to explain it." 
In sum, the basic origin of dependency is formed by Karl Marx's classical analysis of imperialism. Dependency as a theory is an expansion of Marx interpretation of history extended to a problem in world scale. But while Marxism pictures the society, and classes as actors, dependency theory and its apologists look at the international system, seeing states rather than individuals, as actors, with a division into bourgeoisie states and proletariat states. The dependency theory takes a view of development, giving attention to international and transnational influences on questions of development (Bruce and Harvey 1981). Its proponents draw mainly from Latin America and Africa in the likes of Herinque Cardoso, Paul Baran, Andre Gunder, Daniel Offiong, Walter Rodney etc.

The dependency theory asserts that two distinct economic classes exist in the world: the developed North, and the underdeveloped South (Dingson 2001). In its economic relations, the world is divided into the wealthy and poor countries. The global economic relationships operate in such manner that the poor states are kept impoverished and are economically dependent on the rich states. Speaking on this, Theotorio Santos contained that "... a certain group of countries have their economy conditioned by the development and expansion of another economy to which the former is the subject" (Santos 1970). While admitting that the world is a system where there is interdependence, the dependency theory subscribes that in the interdependency, one is more dependent than the other, and in a manner that is economically unfavourable to the dependant. In its postulation of the division of the world into two economic sub-systems, the theory employs the use of terms like Third World, South, Periphery, Underdeveloped etc to refer to the poor economically less developed part of the world (Bruce and Harvey 1981). Africa, Asia, South and Central 
America, constitute this world (Rourke 1997). The assumption of the dependency theory extends to the characterization of the imbalanced character of the global economic system in this order:

1. The economically developed countries lie in the North, and the underdeveloped in the Southern hemisphere. Hence the designations: North and South countries.

2. Evidenced by the GNP and income per capita, the North is wealthier than the South.

3. The North contains about $75 \%$ of the goods and services produced in the world.

4. The North is industrialized with greater part of the working population engaged in industry rather than agriculture. The opposite holds in the South.

5. The underdeveloped South is the producer of raw materials and market for the finished and manufactured goods of the North.

6. Foreign penetration lead to large scale distortions in the structure of peripheral economies, which in turn result in intense social conflict and ultimately in harsh state repression in dependent societies.

7. The South is comprised of mainly erstwhile colonized people;

8. Life expectancy is low in the South, with attendant poor nutrition and diseases.

9. The countries of the South are steeped in crisis of rural poverty, urban unemployment, crisis of governance and of leadership (Rourke 1997). 


\section{Global Economic Imbalance and the Take of Dependency Theory}

In its explanation for the global economic inequality, the dependency theory assumes that the crisis of the South is largely a reflection of her bitter historical experiences (Gambo 1999). The theorists hold that underdevelopment and its perpetuation is attributed to a number of factors like the Atlantic slave trade; colonialism, and neo-colonialism which have sustained the development differentials between the developed countries of Europe and America, and the underdeveloped countries of the Third World. As has been stated elsewhere, the making of the South/Third World is admittedly a creation of international imperialism (Enuka 2001).

This creation as reflected by Daniel Offiong, Walter Rodney, Andre Frank among others, has a historical process which in their analysis, is centered on the triple tragedy of slave trade, colonialism and neocolonialism Slave trade involved the carting away of able-bodied men and young women who constituted the cream of the African society and the active sector of the population. This human hemorrhage inflicted on Africa a massive loss to the African labour force. The import of this is that the lost of the active sector of the population could have engineered developmental progress in Africa. It follows that during the many years of the nefarious trade on human beings, Africa's economy stagnated whereas that of Europe and America (the recipients of the sold Africans) transformed themselves into industrial capitalist powers. Standing on this conviction, the dependency theorists aver unwaveringly that the Atlantic slave trade was a factor in African underdevelopment and condition for dependence. Buttressing that the transatlantic slave trade was by every inch of its operation and performance under developing to Africa's economy, and 
responsible for the continent's marginalized status in the contemporary global rankings, Rodney (1972) reveals that "The removal of millions of young adults who constituted human agents of scientific and technological inventions as a result of the European slave trade represented a direct block to Africa."

Offiong adds that "In the 400 years of the trade, not less than 15 million Africans were enslaved...these were the most vital of the population...the result was that while Africa...contributed immensely to the development of Europe, Africa became a victim of underdevelopment" (Offiong 1980: 91). Referring to the same phenomenon, Nnoli, argued that "It took a deadly toll of the capacity of the Nigerian peoples for a rapid transformation of themselves and their environment... in addition it diverted attention away from local creative potentials and resources by focusing on the procurement of slaves" (Nnoli 1981: 94). As Wallerstein (1976) would surmise "The slave trade served as the cutting edge of the peripherialization of Africa..." Besides the drain of Africa's active labour force, the steps concomitant with the procurement of slaves disrupted agricultural practice which was the mainstay of African economy at the time, given the agrarian structure of the society and its economy. Slaves were procured amidst intertribal wars ignited by the European slave buyers. Under such circumstance of war which produced war captives as commodities for the slave market, meaningful economic progress was unattainable.

As a part of the strategy and process of keeping Africa perpetually underdeveloped, colonial imperialism was introduced. Colonialism is direct political control of one over another. It captures the situation where a country exercises political domination over another by assuming control of the machinery of government and directing the affairs of that society. It is a phase of 
the process of imperialism. In this, economic activities became monopolized, preventing the rise of indigenous entrepreneurial class. Where native initiatives were likely to endanger the colonial interest, it was quickly stifled. Through this process, the economy of the colonized South became incorporated into the world capitalist economy in a subjugated position. This caused the destruction of the South's rich and varied political systems and social structures, and the creation of new productive economic activities based on the needs of the foreign capitalist countries. Colonial education was also carefully structured so as to perpetuate dependency. The subjects taught at schools were designed to impose upon Africans the Europeans mythical racial superiority and the African inferiority. "Colonial education was an instrument to serve the European capitalist class in its exploitation of Africa" (Rodney 1972: 275)

After colonialism came neocolonialism. It is the assumption of the dependency theory that decolonization was false, which resulted in neocolonialism (Offiong 1981). Neocolonialism in all of its ramifications, fetched Africa, and the affected Third World states clientele sovereignty and fake independence. Neocolonialism explains the situation in which a country is in theory, independent and has all the outward trappings of international sovereignty, but in reality its economic system and thus its political policy is directed from outside (Nkrumah 1995). It is the practice of granting a sort of independence by the metropolitan power, with the concealed intention of making the liberated country a client state and controlling it effectively by means other than political ones. To the development question of Africa, and indeed the third world, neocolonialism is more insidious and dangerous than the old colonialism. In spite of political independence, the pattern forcibly instituted by 
colonialism survived unscathed. By the use of economic power, foreigners buy political power in the countries of the South. The roles and influences of multinational and transnational corporations are too obvious to detain us here. It was for this that Gambo (2001: 110) posited that "The termination of colonial rule...did not bring real independence in true sense of it, but a more subtle and wisely crafted form of control"

Neocolonialism not only prevents its African victims from developing their economic potential for their own use, but it controls the political life of the country, and supports the indigenous bourgeoisie in perpetuating the oppression and exploitation of the masses. Under neocolonialism, the economic systems and political policies of independent territories of African states are managed and manipulated from outside, by international monopoly finance capital in league with the indigenous bourgeoisie. Dependency theory assumes that the neocolonial economy of the underdeveloped societies are characterized by expatriate domination of investment opportunities, made possible by access to credit, technology and managerial skills necessary for industrial production, and that this situation inhibits the accumulation and re-investment of capital by indigenous entrepreneurs who lack resources necessary to compete with vertically integrated Multinational Corporations

The dependency theory is optimistic on the solvability of the South's problem. A change in the international economic order is advocated as the sure pathway to break the tenacious circle of poverty of the Third World countries. While some apologists of the dependency school believe that development for the South can be achieved by restructuring the international economic system which remains stacked against the developing South, others, those of the radical wing of dependency are opposed to that belief. Their 
advocacy is that the developing countries of the South should delink from the West and the present lopsided global economic order. The question of whether or not this is feasible has remained a troubling and sharply contested one among scholars and analysts.

\section{Dependency Theory: A Critique}

Regardless of the seemingly sound and logical methodological tradition of the dependency school, the theory has not escaped the critical lenses of scholars. Sudden ascendancy of the theory as the dominant paradigm in the analysis of development and underdevelopment has been accompanied by theoretical controversies.

Lall (1975) challenged the methodological and conceptual correctness of the propositions underlying a number of dependency studies. He argues that the characteristics to which underdevelopment in dependent countries are generally attributed are not exclusive to those economies, but are still found in the socalled non-dependent economies of the North as well. The socioeconomic problem of unemployment for example, taken to be an exclusive index of the South, is rather universal, and not the peculiarity of the South. Lall adds that those problems and similar challenges are characteristic of capitalist development in general and not necessarily only of dependent capitalism (Lall 1975).

The point is made that if crucial features of dependence can also exist in both dependent and non-dependent economies, then the whole conceptual scheme upon which dependency theory is based is defective. Inspite of the apparent and indubitable methodological inadequacies of the dependency theory, the dependency theorists nevertheless acknowledge its explanatory potentials. For instance, Walter Rodney in his seminal work, How Europe Underdeveloped Africa, has been able to use historical data 
and facts to substantiate his thesis that the development of Europe is the cause of underdevelopment of Africa (Okereke and Ekpe 2002). Yet the theorists have come under critical attack for their failure to employ value theory in their analysis as well as the theory's attempt to confuse commodity production with the capitalist mode of production. Kay argues that if the dependency theorists fail to incorporate the law of value in their analysis, the best they could achieve "...was a historical account of the process of underdevelopment... which collapses into hopeless contradiction in the face of close investigation" (Okereke and Ekpe 2002: 77).

The dependency theory employs geo-political and socioeconomic factors in making distinctions between the two identified worlds. But clear enough, this definition lacks precision, and the categorization is replete with noticeable flaws. Defining the North and the South for example by employing the terms 'development' and 'underdevelopment' quickly puts one fast enough to a fix. Oftentimes the use of the terms can be deceptive and ambiguous. As has been demonstrated by many scholars, development is a many sided process, and should not be used in exclusive economic sense (Chuka 2004). Rodney (1972) argues that the terms are relative, not universal because every people have developed in one way or the other. Conceptualization of the terms should consider both the moral and economic angles of underdevelopment. For as Rodney reasoned, if underdevelopment were related to anything other than comparing economies, then the most underdeveloped in the world will be the United States of America, "which practices external oppression on a massive scale, while internally there is a blend of exploitation, brutality and psychiatric disorder" (Rodney 1972; 22).

Further still, the use of the term 'developed' countries by the dependency theory is somewhat misleading. It has the 
connotation of absoluteness, as if there is any country anywhere in the world that has come to that point beyond which there is no other room or need for progress and growth. This is doubtful. As opined by some, the terms 'more developing' and 'less developing' should rather be a better term, since all economies both those of the North and South are still growing and progressing. The difference lies in the extent and level of the progress.

The notion of the less-developed countries as synonymous with the South because it pertains to countries in the Southern hemisphere is equally misleading. Cyprus and Malta are European countries sharing indices of underdevelopment, and active in the Third World politics. Again, in its geo-political categorization of the world, the dependency theory sees Asia as part of the less developed world, yet the industrialized and rich Japan is located in Asia. Confusion with the dependency categorization is in the area of proper economic distinctions. The theory falls often into the error of projecting the less developed world as though it is a homogeneous whole. It is obvious that the countries of the South do not operate on equal grounds economically.

One doubts if there can be a reasonable equation between South Africa for instance and Nigel Republic, or if Brazil and Somalia can correctly fit into any equal comparison. Yet these countries are homogeneously grouped into one as Third World countries. Wrong enough, the theory groups the so-called Third World under one label, with the inclusion for instance of both huge India and micro states like Tuvalu. As Rourke (1997) contains, the World Bank recently divided the countries of the world into four economic groups on the basis of per capita GNP: Low income; Lower middle income; Upper middle income; High income. The problem here is that while the North is normally construed to be the High income group, conversely, Kuwait, Singapore, which are 
classified as part of the South fall into the High income group with the North. Another problematic is how to treat the former communist countries of the Eastern Europe, none of which falls neatly into the North-South dichotomy. The International Monetary Fund's designation often refers to them as CITs: Countries in Transition (Rourke 1997). For this and more other reasons, the dependency theory of underdevelopment has been accused of possessing gaps needing to be filled up and ambiguities to be resolved.

Also, the scholars belonging to the modernization school are very critical of the claims of the dependency theory (Ibezim 2001). The modernization school asserts that the failure of the South to develop, essentially owe to their inability to modernize. To modernize means to westernize i.e following after the developmental steps that saw the West to economic greatness. Modernizers reject and refute the claim of the dependency that the causal explications for Africa's and indeed the Third World's underdevelopment is exogenous, asserting that the trouble with the South's advancement and development is endogenous, and locatable within them.

In line with this thought, and as a radical response to Rodney's over celebrated argument that Europe underdeveloped Africa, Joshua Agbo came up with his piece, How Africans Underdeveloped Africa. Agbo's thesis is that rather than Europe, Africa should be blamed for the underdevelopment of Africa. Following from this line of argument, the dependency theory is grossly inadequate in its failure to blame Africa's underdevelopment on internal factors like bad leadership and corruption. Though external factors may be explanatory basis for the failure of development in Africa and the Third World, but 
corruption and bad leadership are unarguably issues that have debilitated the African states and frustrated development efforts.

Holding that the coming of European imperialism was, from the point of view of the colonized, disastrous because their economies have come to be victims of capitalist exploitations and underdevelopment, the dependency theorists suggests as answer, that the immediate solution beyond conjectures lies in the maximum autarchic separation of underdeveloped societies from the global capitalist economy which, they believe, is choking them to death. But in contradistinction to the dependency's recommendation of a break from the existing international economic superstructure, I argue that given the current realities of the contemporary international system, the non-capitalist economies cannot for now, withdraw from the existing world market. The level of technological development in today's world, and the level of socio-economic integration of the world have made any idea of autarky an illusory one.

Moreover, the North will be most unwilling to allow a delinking or restructuring of the global economic order, for as Njoku would say, it is on the basis of North-South asymmetrical relationship that the developed countries derive their appellation and classification as developed countries (Njoku 1998). It is therefore, doubtful if the developed countries will like to commit class suicide by allowing global spread of development, such that go on in their countries. In its generalized study of Africa's relationship with Europe, the dependency theory asserts that underdevelopment is a consequence of unequal relationship that saw the emiseration of developing economies of the South (Rodney 1972). Contrarily, Njoku (1998) argues that the issue is not whether or not backward countries of the South benefit from their coexistence with the developed countries of Europe. The 
problem rather is how the poor countries can pursue selective policies that would permit them to derive the benefits of the positive aspects of their links with the developed countries without simultaneously exposing their weak economies to the deleterious and detrimental impulses emitted from the economies of the developed countries. Dependency theorists and apologists play down on the contributory role of the local African oppressors and collaborators to Africa's own undoing, especially through their connivance with their foreign masters.

\section{Conclusion}

As has been clearly demonstrated by this paper, dependency theory, no doubt has the qualifications as a theory among other theories within the discipline of International Relations for comprehension and analysis on development and underdevelopment discourses. Through the theoretical lenses of dependency, the development differential between the North and the South countries of the globe has been elucidated and amplified. As has been shown by this paper, the theory has described the nature of the international economic relations, explained how and why conditions of domination and inequality in economic levels of the nations of the globe occur, and prescribed solutions to end the enduring global economic inequality.

But be that as it may, the theory's blame of failure of development (in the South) on the Atlantic slave trade, colonialism and neocolonialism, has doubts. The obvious and grievous incidences of bizarre corruption by the political class, terribly flawed acts of governance, and frequented internecine conflicts, found to be replete in the Third World societies, have in real terms perforated the theoretical balloon of the dependency school. Therefore, the wholesomeness of the theory's explanations for the 
imbalance in the global economic order lacks total acceptance. The position of this paper is that for a balanced understanding and explication of why some parts of the world are rich and others poor to be ascertained, attention should be given to both endogenous and exogenous considerations. However, the observed flaws inherent in the methodological traditions of dependency have not in the least projected the theory to the realm of irrelevance.

\section{Chuka Enuka}

Department of History and International Studies

Nnamdi Azikiwe University, Awka chukaenuka@yahoo.com

\section{References}

Agbo Joshua (2010) How Africans Underdeveloped Africa: A Forgotten Truth in History. Ibadan: Kraft Books Limited.

Ake Claude (1981) A Political Economy of Africa. Ibadan: Longman

Bruce Russett and Harvey Starr (1981) World Politics: The Menu for Choice. USA: Freeman and Company

Chinweizu (1978) The West and the Rest of Us. London: Nok Publishers

Chuka Enuka (2004) "Making of the Third World: A Historical Analysis" Journal of Development and African Studies, Vol. 2, No. 5

Dumont Rene (1988) False Start in Africa. London: Earthscan Publications 
Gambo Audu (1999) "African Diaspora and the Crisis of Development in Africa: Reinforcing the Reparations Question." In Alli Warisu (1999) Africa and the African Diaspora: Aspects of an Experience. Jos: Mazlink Nigeria Limited.

Ibezim E. O (2001) "Modernization and Dependency Theories:

Relevance to Development in Developed and Developing Countries" in Ibezim E.O and Ajaegbo D. I (2001) Readings in Political Economy. Onitsha: West and Solomon Publishing Compant Limited.

Jackson Robert and Sorenson Georg (2007) Introduction to International Relations: Theories and Approaches. New York: Oxford University Press.

Lall S (1975) "Is Dependency a Useful Concept in Analyzing Underdevelopment." World Development. Vol.2, No. 11, pp.799-810.

Njoku Ndu L (1998) Studies in Western Imperialism and African Development. Owerri: Tonyben Publishers

Nkrumah Kwame (1995) Neocolonialism: The Last Stage of Imperialism. New York: International Publishers.

Nnoli Okwudiba (1981) Path to Nigerian Development. Senegal:

Codesria

Nwankwo B. C (1998) "Colonialism and its Impact in Africa" in Emezie C. E and Ndoh C. A (eds) African Politics. Owerri: Achugo Publications.

Offiong Daniel (1981) Imperialism and Dependency. Enugu: Fourth Dimension

Okereke O. O and Ekpe A. E (2002) Development and Underdevelopment: Politics of the North-South Divide. Enugu: Jogn Jacobs 
Onimode Bade (1981) "Imperialism and Nigerian Development" in Nnoli Okwudiba Path to Nigerian Development. Senegal: Codesria

Rodney, Walter (1972) How Europe Underdeveloped Africa.

London: Bogle L'Ouverture Publication

Rourke John (1997) International Politics on the World Stage. USA: Dushskin

Santos Theotonio (1970) "The Structure of Dependence" American Economic Review

Thirlwill A. P (2003) Growth and Development with Special Reference to Developing Economies. New York: Palgrave Macmillan

Wallerstein Immanuel (1976) The Political Economy of Contemporary Africa. California: Sage Publications

Williams Gavin (1980) State and Society in Nigeria. Idanre: Afrografika Publishers 